\title{
THE BALANCED SCORECARD AS A STRATEGIC PERFORMANCE CONTROL TOOL AND ITS LINK TO THE ECONOMIC PROFIT MEASUREMENT- EVA AND MVA: A LITERATURE REVIEW
}

\author{
Anbalagan Krishnan ${ }^{1}$ \\ Curtin University of Technology, East Malaysia \\ R. Ravindran ${ }^{2}$ \\ University of Tun Abdul Razak, West Malaysia
}

\begin{abstract}
The organizational performance measurement and control system is vital to sustain the business in all economic environments. Organization requires a control system that measures the performance strategically. This paper gathers the literature discussion of one such popular integrated strategic performance control system, the balanced scorecard approach (BSC). The discussion focuses on BSC approach on facilitating the implementation of organizational strategic and its link to the economic profit measures. Two popular economic profit measures, the Economic Value Added (EVA) and Market Value Added (MVA) are discussed in detail from various researchers point of view. The paper highlights the difference between these two measures and difference with the Return on Investment (ROI). The limitation of the economic profit measure is also highlighted in the discussion. As conclusion the link between the BSC strategic performance control tool and the economic profit measures are noted. This paper provides detailed discussions of both BSC strategic tool and economic profit measures based on literature review.
\end{abstract}

Keywords: BSC performance strategic control tool, economic value added and market value added.

\footnotetext{
${ }^{1}$ Senior Lecturer for Accounting Department of Accounting and BIS School Business, Curtin University of Technology (anbalagan.k@curtin.edu.my)

${ }^{2}$ Associate Professor \& Research Supervisor Faculty of Business Administration
} 


\section{INTRODUCTION}

Various authors argued that the use of traditional accounting performance system is not suitable for the current business environment particularly to be used as planning and control tools (Bromwich \& Bhimani, 1994; R.S. Kaplan, 1983; Lucas, 1997). According to Lucas, to succeed in the present dynamic business environment, companies should link their strategies to quality improvement, increased flexibility in meeting customers' individual requirements, reduced lead times, inventories and production cost (1997). The changes in the nature of business operations and stiff competition force companies to adopt a different kind of performance control system not solely depending on traditional ways of measuring. The BSC control system approach facilitates a long term growth and applicable to current business condition where competitiveness and economic condition is uncertain.

\section{BALANCED SCORECARD AS A STRATEGIC MANAGEMENT TOOL}

The Balanced scorecard is a strategic management tool developed by Kaplan and Norton (1992) to complement traditional financial measures of business unit performance (cited in Lipe, 2000). Kaplan and Norton (1996b) noted that the business unit measures primarily concentrate only on lagging measures that are financial indicators of performance and lack using the leading indicators which are non-financial measures. The BSC approach is an integrated set of leading and lagging performance measures designed to capture the organization's strategy (Lipe \& Salterio, 2000). The approach contains a diverse set of performance measures, spanning financial performance, customer relations, internal business processes, and the organization's learning and growth activities. The BSC strategic performance control tool supplements the traditional financial measures with three other non-financial dimensions - customer, internal business and; learning and growth. These non-financial dimension leading measures provide solution to the weakness and drawbacks identified in the traditional control system. For instance, the BSC approach overcomes the traditional system's inability to link company's long-term strategy with its short-term actions. Kaplan and Norton describe the importance of 
measuring all these perspectives which is to enable companies to track financial results while simultaneously monitoring progress in building the capabilities and acquiring the intangible assets they would need for future growth (2007,p150). Thus, the BSC strategic tool was developed to overcome deficiencies in the financial accounting model, which fails to signal changes in the company's economic value as an organization makes substantial investments (or depletes past investments) in intangible assets, such as the skills, motivation, and capabilities of its employees, customer acquisition and retention, innovative products and services, and information technology (Robert S. Kaplan, 2001a).

\section{THE BSC APPROACH MANAGING THE IMPLEMENTATION OF STRATEGY}

Many research scholars provide positive notes on companies that have implemented the BSC strategic tool and noted improvement in performance. The tool helps the organization to remain viable in a changing and ever more competitive business environment (W.Hilton, 2008). Hendricks et al. (2004) noted a number of benefits that organizations gained from implementing this strategic tool as follows:

o Better management understanding of the linkages between specific organizational decisions and actions, and the chosen strategic goals;

o A redefinition of relationships with customers;

0 Re-engineering of fundamentals business processes; and

o The emergence of a new corporate culture emphasizing team effort among organizational functions to implement the firm's strategy.

Companies are expanding the use of the balanced scorecard approach and employing it as the foundation of an integrated and interactive strategic management system as noted by Kaplan and Norton (2007). According to the authors firms are using BSC tool for other strategic reason such as (R.S. Kaplan \& Norton, 2007) to:

o Clarify and update strategy;

o Communicate strategies throughout the company;

o Align unit and individual goals with the strategy;

o Link strategic objectives to long-term targets and annual budgets; 
o Identify and align strategic initiatives; and

o Conduct periodic performance reviews to learn about and improve strategy.

Above all, many researchers noted that the BSC control system is widely accepted mainly because the system translates organizations' vision and mission into action. At initial stage this strategic tool was developed to suit the manufacturing industry, but is also getting popular in service industry due to increasing competitiveness, for instances hospital, education institutions, charity organization and etc. According to Paranjape et al. a survey confirmed that of all the performance measurement and control system, the BSC is the most popular, least criticized and is widely implemented (2006). A survey conducted by Silk (1998) estimates 60 percent of Fortune 1000 firms have experimented with the BSC (cited in Lipe, 2000). Lipe noted that the adopters of BSC approach among all include KPMG Peat Marwick, Allstate Insurance and AT\&T (2000). According to Darrell Rigby, based on the "Management Tools Survey 2003" the key informants from these organizations ranked the BSC $8^{\text {th }}$ overall in satisfaction (2003). On similar note, based on data by Gartner, the Connecticut, research based organization, suggests that over $70 \%$ of large US firms had adopted BSC by the end of 2001 (Neely, Marr, Roos, Pike, \& Gupta, 2003). A survey conducted by Bain \& Company revealed that out of 708 companies, 62 per cent of responding organizations is using the BSC, a higher adoption rate than some other well-known management tool like Total Quality Management, Supply Chain Integration or Activity Based Management (Hendricks, Menor, \& Wiedman, 2004). In Malaysia a study undertaken by Abdul Rahman et al., in 1998, Sulaiman et al., in 2002 , Sulaiman et al., in 2004 and Jusoh et al., in 2006 provide some evidence of using BSC approach, however as a result of small sample size is insufficient to validate the evidence firms at Malaysia is widely using BSC approach.

The strategy tool is popular as compared to various other management performance control systems mainly because the system comprises both financial and non-financial measures. The system consists of traditional financial indicators that measures include the accounting profit and economic profit. The economic profit measures are widely used to measure the movement of firm market value and shareholder's growth and 
wealth. The non financial and financial measures that includes the economic profit indicator provide organizations necessary information to meet the basic managerial accounting activities and objectives, such as 1) providing information for decision making and planning, 2) assisting managers in directing and controlling operational activities, 3) motivating managers and other employees toward the organization goals, 4) measuring the performance of activities, subunits, managers, and other employees within the organization and 5) assessing the organization's competitive position, and working with other managers to ensure the organization's long-run competitiveness in its industry (W.Hilton, 2008).

\section{ECONOMIC PROFIT PERFORMANCE CONTROL MEASURES AND BSC APPROACH}

The economic profit measure is vital to measure the firm performances. The economic profit is a more intuitively satisfying measure of performance than the most traditional accounting measures (Baum.L, 2004). According to the authors the latter measures annual dollar income to the suppliers of common equity capital after charge for the cost of dept capital alone, the former measures income after charging for the cost of common equity capital. Based on analysts the economic profit is a true measure of performance - outputs minus inputs- than net income ever could be (2004, p. 82).

The traditional financial measures which are primarily measures raw accounting values such as Return on assets (ROA), Return on investment (ROI) and Return on sales (ROS) are short term focuses and provide insufficient detail of organization growth. The accounting profit measures do not incorporates the cost of acquiring capital and switching cost. As a result firm needed an economic profit measure in addition to the accounting profit measures. Among many economic profit measures two widely adopted measures are Economic Value added (EVA) and Market Value added (MVA). According Kyriazis and Anastassis (2007), the Economic Value Added measurement gains a new meaning in contrast with the traditional approach which is merely based on the simple notions of accounting profits and the relevant ratios derived from them, such as the return on equity (ROE) and the return on assets (ROA). 
Many firms include the Economic Value Added and Market Value Added as part of financial perspective of Balanced Scorecard strategic tool. EVA measures the firm contribution to the shareholder. The concept of EVA is relatively new to the financial press and the term EVA was copyrighted by the consulting firm Stern Steward \& Company (Steward \& Bennet, 1991). EVA is a performance measure based on operating income after taxes, the investment in assets required to generate the income, and the cost of the investment in assets (or weighted average cost of capital). According to Steward, EVA is for a single period is defined simply as operating profits less a capital charge which expressed as follows (1991, p.137):

$$
\text { EVA }=\text { NOPAT }- \text { WACC } x \text { Capital }
$$

Where:

NOPAT : Net Operating Profit after Tax

WACC : Weighted Average Cost of Capital, and

Capital : Total Debt + Equity

The EVA is dollar-based and therefore the maximization of EVA correlates with wealth maximization. According to Stewart (1992), positive EVA means the firms is providing a higher return than shareholders can earn elsewhere, and thus deserve to sell for a premiumto-book value. On the other hand, the firms with a zero EVA just meet investor expectations, and thus should sell for book value and negative EVA firms should sell at a discount-to-book value (cited in Griffith, Summer 2006).

Three essential elements used in calculating EVA are operating income after tax, investment in assets, and the cost of capital (Hansen \& Mowen.M., 1997), is similar to residual income (RI) accounting profit measure. On the other hand, EVA overcomes weakness that identified in Return on investment (ROI). ROI measures the success of a company or division by comparing its operating income to its invested capital and expressed in percentage. The primary limitation of ROI is that it can encourage managers, who are evaluated and rewarded based on achievement of ROI, to make investment divisions that are in their own best interest, while not being in the best interest of the company as a whole (Morse, Davis.J., \& Hartgraves, 1996). Whilst the primary strength 
of EVA is that it provides a measure of wealth creation that aligns the goals of divisional or plant managers with the goals of the entire company (Brewer, Chandra, \& Hock, 1999). Thus, it eliminates the disadvantage of ROI measurement and helps the managers to act in the best interest of the company.

However, researchers have identified some limitation with EVA such as size difference, financial orientation, short- term orientation and resultsorientation. The detail of these limitations highlighted as follows:-

o EVA does not control for size differences across plants or divisions, this means, larger the plant or division will have a higher EVA relative to its smaller counterparts (Hansen \& Mowen.M., 1997; Horngren, Foster, \& Datar, 1997). Even though EVA is more effective than ROI at aligning plant managers' goals with corporate goals but it does not control for size differences across organizational units like ROI does (Brewer, Chandra, \& Hock, 1999).

o EVA is a computed number that relies on financial accounting methods of revenue realization and expense recognition. According to Horngren et al., managers can manipulate these numbers by altering their decision making processes if they motivated to do so (1997).

o EVA approach overemphasizes the need to generate immediate results; therefore, it creates a disincentive for managers to invest in innovative product or process technologies. This is because any innovation in product does not give immediate return and the result of this innovation is only realized in long term. This means the costs or expenses on this innovation are recognized immediately but the benefits or revenues associated with this initiative are not recognized until a few years down the road. The recording of cost in current period has impact on EVA. EVA is form of managerial remote control that forces managers to put undue emphasis on the short-term bottom line (Brewer, Chandra, \& Hock, 1999).

o EVA is classified as results-oriented financial numbers that are accumulated at the end of an accounting period which does not provide much help to identify the root causes of operational inefficiencies. Therefore, these measures offer limited useful 
information to people charged with the responsibility of managing business processes.

Despite all this limitations, EVA is still a widely used indicators to measure wealth creation and is used to help align managerial decision with firm preferences (Brewer, Chandra, \& Hock, 1999). The adoption of this value-based measures, has coincided with increasing pressure from capital markets and corporate control markets for managers to focus their strategies on value creation (Haspeslagh, Noda, \& Boulos, 2001; Hawawini, Subramanian, \& Verdin, 2003). According to Chen and Feng (2006,p.736) value creation occurs only when firms earn returns greater than the cost of capital, which implies that value creation is a reasonable proxy for economic performance.

The Market value added (MVA) economic profits measures complement well to EVA metric performance. A companion metric, Market Value Added (MVA), purports to compare the firm current market value to the value of capital provided over time by its investors expressed as follows (Baum, Sarver, \& Strickland, 2004).

$$
\text { Market Value Added = Market Value - Capital }
$$

According to Griffith, MVA is the difference between the market value of a company (both equity and debt) and the capital that lenders and shareholders have entrusted to it over the years in the form of loans, retained earnings, and paid in capital (Summer 2006). He further noted that MVA is a measure of the difference between "cash in", i.e., what investors have contributed, and "cash out", i.e., what they could get by selling at today's price. If MVA is positive, it means that the company has increased the value of the capital, and thus created shareholder wealth, on the other hand if the MVA is negative, the company has destroyed wealth (Griffith, Summer 2006, p. 75). According to Steward, MVA is "the market value that management adds to, or subtracts from, the capital it has employed" (1991, p.153). The author further noted that MVA equals the present value of the firm's future stream of EVAs'. According to Hawawini (2003) the difference between EVA and MVA is stated that former is indicating economic profit, reflects operating performance in a given year, while the later is indicating market-to-book value, reflects the 
market's expectations of the firm's future operating performance. The difference between these two economic profit measures with ROA is noted by Chen and Lin that ROA is not equivalent to examining what drives value creation or economic performance is because this raw accounting measures account neither for the cost of capital unlike the EVA and MVA (2006).

According to Griffith the portfolio managers, institutional investors, academics, consultants and corporate managers are increasingly using EVA and MVA raking database for value based analysis (2006). The author further noted that many researchers undertake extensive research on these two new economic performance indicators, for instances, Bacidore, Boquist, Milbourn, and Thakor (1997), Ferguson and Leistikow (1998), Mclaren (2000), Kramer and Peters (2001), Ray (2001), Weaver (2001), and Zwell and Ressler (2000), examine the shortcomings and virtues of EVA model; Freedman (1998), Farsio, Degel and Degner (2000) and Garwey and Milbourn (2000), examine the case for forecasting stock performance based on EVA and MVA; Biddle, Bowen, and Wallace (1997), Dodd and Chen (1997, 2001), Sheikholeslami (2001), and Shrieves and Wachowicz (2001) compare EVA to other measures of performance; Machuga, Pfeiffer, and Verma (2002) find that analysts do not appropriately use the information contained in EVA and appear to overweight it (cite in Griffith, Summer 2006, p. 75).

\section{CONCLUSION}

The EVA and MVA are the popular measures of economic profit in addition to accounting measures. The economic profit measures are necessary as a result of market uncertainty and the shareholders are concern with depositing fund in the business in order to get a good return. EVA resembles the traditional residual income accounting measures, while MVA resembles the traditional Market Value-to-Book Value ratio, although its intent is closer to Tobin's Q, the ratio of market value to replacement value of assets. As noted by Brewer (1999) that the EVA and MVA are only one component of the performance measurement system and it must be used together with other balanced set of measures that access the organization in many aspects of performances. 
This view is supported by Stern, Steward and Chew (1996) stated that EVA is not just another performance measure, but it can be part of an integrated financial management system (cited in Kyriazis., 2007, p.72). These economic profits measures together with other financial and nonfinancial measures are necessary to survival of firm in today's business which is competitive and complex. As stated by many research scholars BSC approach is a complete strategic performance management tool looks into economic growth, financial growth, customer satisfaction, business process and learning and growth of employees which well fit into current business environment that is dynamic, competitive and unpredictable. In summary, the BSC approach with economic profit measures is a strategic performance control system provides a well rounded performance measurement tool to implement the firms' strategy and for long term business growth.

\section{REFERENCE}

Baum, C. L., Sarver, L., \& Strickland, T. (2004). EVA, MVA and CEO Compensation. Further Evidence. American Business Review.

Brewer, P. C., Chandra, G., \& Hock, C. A. (1999). Economic Value Added (EVA): its Uses and Limitations. S.A.M. Advanced Management Journal, 64(2), 4-11.

Bromwich, M., \& Bhimani, A. (1994). Management Accounting: Pathways to Progress. Chartered Institute of Management Accountants.

Chen, Y.-M., \& Lin, F.-J. (2006). Source of Superior Performance: Industry versus firm Effects among firms in Taiwan. European Planning Studies, 14(6), 734-751.

Griffith, J. M. (Summer 2006). EVA and Stock Peformance. The Jornal of Investing, 75-78. 
Hansen, D., \& Mowen, M. (1997). Cost management: Accounting and control. Cincinnati. OH: Southwestern Publishing.

Haspeslagh, P., Noda, T., \& Boulos, F. (2001). Managing for value: It's not just about the numbers. Harvard Business Review, 79(7), 6473.

Hawawini, G., Subramanian, V., \& Verdin, P. (2003). Is performance driven by industry-or firm-spedific factors? A new look at the evidence. Strategic Management Journal, 24(1), 1-16.

Hendricks, K., Menor, L., \& Wiedman, C. (2004). The Balanced Scorecard: to adopt or not to adopt?, Ivey BusinessJournal online: available at:www.iveybusinessjournal,com/view_article.asp?intArticle_ID= 527.

Horngren, C., Foster, G., \& Datar, S. (1997). Cost accounting: A managerial emphasis. Upper Saddle River, NJ: Prentice Hall.

Kaplan, R. S. (1983). Measuring performance: a new challenge for managerial accounting research. The Accounting Review, 18(4), 686-705.

Kaplan, R. S. (2001a). Strategic Performance Measurement and Management in Nonprofit Organizations. Nonproft Management and Leadership, 11(3), 353-369.

Kaplan, R. S., \& D.P.Norton. (1992). The Balanced Scorecard-Measures That Drive Performance. Harvard Business Review, 70(1), 71-80.

Kaplan, R. S., \& Norton, D. P. (1996b). Linking the balanced scorecard to strategy. Harvard Business Review, 39(1), 53-79.

Kaplan, R. S., \& Norton, D. P. (2007). Using the Balaced Scorecard as a strategic management system. Harvard Business Review, 150-160. 
Kyriazis., D., \& Anastassis., C. (2007). The validity of the Economic Value Added Approach: an Empirical Application. European Financial Management, 13(1), 71-100.

Lipe, M. G., \& Salterio, S. E. (2000). The Balanced Scorecard: Judgemental Effects of Common and Unique Performance Measures. The Accounting Review, 75(3), 238-298.

Lucas, M. (1997). Standard Costing and its role it today's manufacturing enviroment. Management Accounting, 24(4), 32-34.

Morse, W., Davis.J., \& Hartgraves, A. (1996). Management accounting: A strategic approach. Cincinnati, HO: Southwestern Publishing.

Neely, A., Marr, B., Roos, G., Pike, S., \& Gupta, O. (2003). Towards the third generation of performance measurement. Controlling, 15(3/4), 129-135.

Paranjape, B., Rossiter, M., \& Pantano, V. (2006). Insights from the Balanced Scorecard Performance measurement systgems: successes, failures and future- a review. Mesuring Business Excellence, 10(3), 4-14.

Rigby, D. (2003). Management Tools Survey 2003: Usage up as companies strive to make headway in tough times. Strategic and Leadership, 31(5).

Steward, G., \& Bennet. (1991). The Quest for Value: A guide for senior managers. NY: Harper Collins Publishing.

W.Hilton, R. (2008). Managerial Accounting: Creating Value in a Dynamic Business Environment. New York: McGraw-Hill/Irwin. 